\title{
INTEGRATED ORGANIC AND INORGANIC FERTILIZATION REGIMES ARE INDISPENSABLE FOR APPROPEIATE CANOLA GROWTH AND OIL YIELD \\ Ali, Shaimaa F. ${ }^{1}$; S. A. Ismail ${ }^{1}$; M. A. Ali, ${ }^{2}$ and M. Fayez ${ }^{2}$ \\ 1- Soil, Water and Environment Institute, ARC; Giza \\ Faculty of Agriculture, Cairo University,
}

\begin{abstract}
Canola (Brassica napus L.) cv. Pactol was experimented for growth and seed oil production due to farm yard manure (FYM) and urea in presence of diazotrophic bio-preparates applied in clay and sand soils. Introduction of diazotroph inocula was more supportive to canola grown in sand soil than the corresponding cultivated in clay soil, a phenomenon observed with all growth parameters determined. Among the microbial products, rhizobactren acted more efficiently compared to others. Comparative variations in chemical characteristics of both soils due to diazotroph formulations were very contradicting, some inocula were successful in improving sand properties while others showed more pronounced modifying influence in the heavy textured clay soil. In the majority of cases, response of canola to urea application was more evident in sand than clay soil. On the contrary to the effect of mineral- and biofertilizers, canola grown in clay soil responded, to higher extent, to FYM. Due to various fertilization regimes, no distinct trend, among both soils, was recorded in respect to chemical properties.
\end{abstract}

Keywords: Canola, growth, seed oil, farm yard manure, $\mathrm{N}$-fertilizer, bio-fertilizers.

\section{INTRODUCTION}

The supply of protein and oil is becoming scarce especially in the developing countries. Egypt is facing a widening gap between edible oil requirements and the public production. Most vegetable oils are edible and have been used in food preparation to be more palatable and nutritious. These oils are preferable over the solid animal fats because of health benefits (Khalil and Rehman, 1999).

Application of fertilizers has become a necessity in the crop production of oil seeds, particularly canola, because of the ever increasing demand of the health conscious population of the world. In Egypt, efforts are being made to expand the areas for oil seed crops as much of the edible oil is imported. It is well established that NPK fertilizers are indispensable for better growth and yield of such crops but recently a vast array of reports proved that excessive and repeated use of chemical fertilizers might spoil soil, ground water and pollute even the atmosphere (Kennedy and Tchan, 1992; Mytton, 1993). These problems have renewed the interest in exploring alternative or supplementary non-polluting sources of fertilizers, i.e. organicand bio- fertilizers.

Not much experimental work has been conducted on the use of such amendments on growth and seed oil yield of canola (Yasari and Patwardhan, 2007). Therefore, the present study on effects of some biofertilizer formulations and organic manuring together with mineral $\mathrm{N}$ fertilizer on growth and productivity of canola was planned. 


\section{MATERIALS AND METHODS}

\section{I-Soils}

The top $(0-30 \mathrm{~cm})$ soil samples were taken from Sids Experimental Farm, Agricultural Research Center (ARC), Bani Swef, and privat farm of Samalot, Minia. The former represents clay soils while the latter is sand. Soils were air-dried, crushed, sieved, thoroughly mixed and analyzed for mechanical and chemical properties according to Klute (1982) and Page et al. (1982) respectively. The clay soil is characterised by: $\mathrm{pH}, 7.8 ; \mathrm{EC}, 0.32 \mathrm{dSm}^{-1} ; \mathrm{OM}$, $1.86 \%$; available $\mathrm{N}, 20.5 \mathrm{Ugg}^{-1}$ while the respectives for sand soil are 8.1, $1.15,0.22$ and 5.1 .

\section{II-Canola}

Seeds of canola (Brassica napus L.) cv. Pactol were kindly provided by Oil Crops Research Section, ARC. Prioer to cultivation, seeds were determined for germination rate.

\section{III - Fertilizers \\ III-1- Chemical fertilizer}

The nitrogen levels were applied in the form of urea $(46.5 \% \mathrm{~N})$. Those represented 30,60 and $90 \mathrm{~kg} \mathrm{~N}$ fed $^{-1}$ added to soil and thoroughly mixed before seed sowing.

\section{III-2- Organic fertilizer}

The farm yard manure obtained from Animal Production Farm of Sids Agricultural Research Center was dried at $60^{\circ} \mathrm{C}$ and ground to pass $2 \mathrm{~mm}$ sieve. The organic manure was incorporated into soil at rates representing 10 and 20 ton fed $^{-1}$. The manure is characterized by the following: $\mathrm{pH} .7 .0$; EC, $4.3 \mathrm{dSm}^{-1}$; OC, $18.45 \%$; TN, $1.50 \%$; TP, $0.24 \%$ and TK, $1.50 \%$.

\section{III-3- Biofertilizers}

Five biofertilizer formulations; biogen, cerialen, microben, nitroben and rhizobactren were provided by Department of Microbiology; Soil, Water and Environment Institute, ARC. The respective bacterial members of such products are: 1) Azotobacer spp., 2) Azospirillum spp., Bacillus polymyxa, 3) Bacillus magaterium, Azotobacter spp., Pseudomonas spp., Azospirillum spp., 4) Azospirillum spp., Azotobacter spp. and 5) Rhizobium spp., Azotobacter spp., Azospirillum spp.

Initially, the viability of the product-microorganisms were checked by inoculation into agar plates of selective medium of either inoculum. Peatbased inocula were mixed with Arabic gum and 1\% glucose (w/w) for activating the product candidates. Canola seeds were coated by bacteriapeat mixtures and sown.

\section{IV- Experimentation}

IV-1- Promotion of canola growth and yield via integrated fertilization

Plastic pots (10 cm dia. and $15 \mathrm{~cm}$ depth) were filled with $5 \mathrm{~kg}$ portions of soil. Mineral- $\mathrm{N}$ and organic fertilizers were mixed with soils in the previously mentioned quantities. Soils were supplemented with super phosphate- and 
potassium sulfate-fertilizers at rates equivalent to field recommended levels of 30 and $48 \mathrm{~kg} \mathrm{P} \mathrm{P}_{2}$ and $\mathrm{K}_{2} \mathrm{O} /$ fed respectively. The micronutrients $\mathrm{Fe}, \mathrm{Mn}$ and $\mathrm{Zn}$ were applied at the rates of $10 \mathrm{mg} \mathrm{kg}^{-1}$ soil as $\mathrm{FeSO}_{4}, \mathrm{MnSO}_{4}$ and $\mathrm{ZnSO}_{4}$ while $\mathrm{Cu}$ was added as $2 \mathrm{mg} \mathrm{kg}^{-1}$ in the form of $\mathrm{CuSO}_{4}$. Inoculated or unioculated canola seeds were sown as 10 seeds pot ${ }^{-1}$, which were thinned to 4 seedlings after 15 days. A total number of 576 pots was prepared to represent the various fertilizer combinations present in Figure (1). Pots were arranged in a greenhouse in a completely randomized design with 4 replicates for each treatment. Potting soils were regularly irrigated with tap water along the experimental period to maintain the water holding capacity @ 60\%. At the 45-day growth period, plants were gently uprooted and determined for length and weight (at $70^{\circ} \mathrm{C}$ over night) of roots and shoots. Total contents of N, P and K were estimated according to AOAC (1985). At harvest (180 days after planting), plants were taken and left to air dry for one week. Thereafter, pods were threshed and seeds were separated and estimated for yield. Besides, seed oil content was determined using a Soxhlet apparatus and petroleum ether as a solvent (AOAC, 1985). Soil samples were taken, as well, and estimated for physico- chemical properties adopting the procedures of Page et al (1982) and Klute (1982) for physical and chemical analyses, respectively.

\section{IV-2- Effect of bacterial formulation on soil physical properties}

The short-term effect of bacterial inocula on some physical properties of both soils was monitored. Five kilogram soil- containing plastic pots were inoculated with either microbial preparation at the recommended rate of $200 \mathrm{~g}$ $\mathrm{fed}^{-1}$, besides increased rates equivalent to 400 and $600 \mathrm{~g} \mathrm{fed}^{-1}$. After thoroughly mixing, pots were supplemented with $1 \%$ glucose $(\mathrm{w} / \mathrm{w})$ to activate the introduced and residential communities and watered to keep the WHC @ $60 \%$ along 45 days.

At the end of the experiment, soils were sampled and determined for: particle density by submersion method $\left(2.65\right.$ and $2.68 \mathrm{Mg} \mathrm{m}^{-3}$ for clay and sand soils respectively), bulk density by core method and total porosity which is calculated according to Kulte (1892) as follows:

$$
\text { Total porosity } \%=1-\quad\left(\frac{\text { bulk density }\left(\mathrm{Mg} \mathrm{m}^{-3}\right)}{\text { particle density }\left(\mathrm{Mg} \mathrm{m}^{-3}\right)}\right) \times 100
$$

\section{V-Statistical analysis}

Data were statistically analysed by least significant differences according to Snedecor and Cochran (1980). Linear regressions among variable parameters were recorded as well. 
Ali, Shaimaa F. et al.

Fig. (1) Dendrogram presentation for the various fertilization treatments (FYM, ton fed ${ }^{-1} ; \mathrm{N}, \mathrm{kg} \mathrm{fed}^{-1}$ ).

5896 


\section{RESULTS}

An increase of $12 \%$ in canola dry matter yield was attributed to incorporation into clay soil of 10 ton $^{-e^{-1}}$ of FYM (Table1). Raising the organic fertilization regime to 20 ton fed ${ }^{-1}$ increased biomass yield by $16 \%$. The influence of increasing mineral $\mathrm{N}$ level was more conspicuous where biomass production increased by $25.1 \%$ due to $90 \mathrm{~kg} \mathrm{~N}^{-1} \mathrm{~d}^{-1}$ application. Three out of the five tested diazotroph formulations did obviously stimulate canola dry matter production, estimated increase percentages of $44.7,32.8$ and 24.3 were reported for rhizobactren-, nitroben- and microben-inoculated plants, respectively.

Table. (1): Effect of organic and inorganic fertilization on biomass yield $\left(\mathrm{g} \mathrm{pot}^{-1}\right)$ of canola inoculated with various biofertilizer formulations in clay soil.

\begin{tabular}{|c|c|c|c|c|c|c|}
\hline \multirow{2}{*}{$\begin{array}{l}\text { Mineral N } \\
\left(\mathrm{kg} \mathrm{fed}^{-1}\right)\end{array}$} & \multicolumn{6}{|c|}{ Biofertilizer formulations } \\
\hline & None & Biogen & Ceriale & oben & & Rhizobactren \\
\hline & \multicolumn{6}{|c|}{ FYM (0 ton fed $\left.{ }^{-1}\right)$} \\
\hline 0 & 2.5 & 2.8 & 2.9 & 3.6 & 3. & 4.2 \\
\hline 30 & 2.8 & 3.1 & 3.5 & 3.7 & 3. & 4.6 \\
\hline 60 & 3.4 & 3.6 & 3.9 & 4.2 & 4. & 4.7 \\
\hline \multirow[t]{2}{*}{90} & 3.8 & 3.7 & 3.9 & 4.1 & 4. & 5.0 \\
\hline & \multicolumn{6}{|c|}{ FYM (10 ton fed $\left.{ }^{-1}\right)$} \\
\hline 0 & 2.8 & 3.1 & $3 . \overline{1}$ & 3.5 & 3.7 & 4.0 \\
\hline 30 & 3.2 & 3.6 & 3.7 & 4.1 & 4. & 4.4 \\
\hline 60 & 3.4 & 4.0 & 4.2 & 4.2 & 4. & 5.0 \\
\hline \multirow[t]{2}{*}{90} & 3.5 & 4.0 & 4.0 & 4.2 & 4. & 5.0 \\
\hline & \multicolumn{6}{|c|}{ FYM (20 ton fed $\left.{ }^{-1}\right)$} \\
\hline 0 & 2.9 & 3.3 & $3 . \overline{7}$ & 4.0 & 4.3 & 4.5 \\
\hline 30 & 3.4 & 4.0 & 4.2 & 4.3 & 4.6 & 5.0 \\
\hline 60 & 3.9 & 4.3 & 4.5 & 4.6 & 4.9 & 5.4 \\
\hline 90 & 4.1 & 4.4 & 4.5 & 4.5 & 5.0 & 5.3 \\
\hline
\end{tabular}

As low as $62.5 \mathrm{mg} \mathrm{pot}^{-1}$ of nitrogen was accumulated in untreated canola (Table 2). The highest $\mathrm{N}$ yield $\left(216.6 \mathrm{mg} \mathrm{pot}^{-1}\right.$ in average) was produced by canola supplemented with $90 \mathrm{~kg} \mathrm{~N}^{-1} \mathrm{fed}^{-1}$. Average estimate of plant $\mathrm{N}$ due to biofertilization represented $>90 \%$ of that attributed to mineral $\mathrm{N}$ application. Compared to other inocula, rhizobactren supported $47.0 \%$ increases in $\mathrm{N}$ accumulation in canola tissues over the control, while only $14.2 \%$ was recorded with biogen-inoculated plants. Incorporation into soil of FYM promoted $\mathrm{N}$ assimilation by canola. An average percentage increase of 14.9 was obtained due to addition of 10 ton $\mathrm{fed}^{-1}$, while 20 ton fed ${ }^{-1}$ amended canola recorded an extra increase of $36.4 \%$.

Phosphorus level ranged from 24.0 to $71.6 \mathrm{mg} \mathrm{pot}^{-1}$ being the highest in case of canola supplied with $90 \mathrm{~kg} \mathrm{~N}$ fed $^{-1}$ together with 20 ton fed FYM in presence of the diazotroph preparation rhizobactren (Table 3 ). In this 
Ali, Shaimaa F. et al.

particular treatment, $\mathrm{P}$ was $>200 \%$ higher than that in untreated plants. Fluctuations in potassium contents behaved in almost similar trend as phosphorus.

Table (2): Nitrogen yield $\left(\mathrm{mg} \mathrm{pot}^{-1}\right)$ of canola due to different fertilization treatments applied in clay soil.

\begin{tabular}{|c|c|c|c|c|c|c|}
\hline \multirow{2}{*}{\begin{tabular}{|l|}
$\begin{array}{l}\text { Mineral N } \\
\left(\mathrm{kg} \mathrm{fed}^{-1}\right)\end{array}$ \\
\end{tabular}} & \multicolumn{6}{|c|}{ Biofertilizer formulations } \\
\hline & None & Biogen & Cerialen & Microbe & Nitroben & Rhizobactren \\
\hline & \multicolumn{6}{|c|}{ FYM $\left(0\right.$ ton fed $\left.^{-1}\right)$} \\
\hline 0 & 62.5 & 98.0 & $81 . \overline{2}$ & 97.2 & 99.9 & 111.3 \\
\hline 30 & 84.0 & 94.6 & 108.5 & 116.6 & 117.8 & 149.5 \\
\hline 60 & 124.1 & 119.7 & 142.4 & 157.5 & 170.2 & 178.6 \\
\hline \multirow[t]{2}{*}{90} & 172.9 & 172.0 & 177.5 & 188.6 & 209.3 & 190.0 \\
\hline & \multicolumn{6}{|c|}{ FYM (10 ton fed $\left.{ }^{-1}\right)$} \\
\hline 0 & 82.6 & 96.1 & $96 \overline{1}$ & 106.8 & 111.0 & 130.0 \\
\hline 30 & 114.0 & 131.4 & 133.2 & 153.8 & 153.3 & 171.6 \\
\hline 60 & 141.1 & 165.0 & 176.4 & 153.3 & 186.8 & 213.8 \\
\hline \multirow[t]{2}{*}{90} & 173.3 & 198.0 & 204.0 & 214.2 & 222.2 & 262.5 \\
\hline & \multicolumn{6}{|c|}{ FYM (20 ton fed $\left.{ }^{-1}\right)$} \\
\hline 0 & 97.2 & 113.9 & 122.9 & 140.0 & 146.2 & 159.8 \\
\hline 30 & 130.9 & 174.0 & 168.0 & 172.0 & 181.7 & 202.5 \\
\hline 60 & 181.4 & 202.1 & 213.8 & 218.5 & 230.3 & 256.5 \\
\hline 90 & 215.3 & 237.6 & 245.3 & 247.5 & 275.0 & 294.2 \\
\hline
\end{tabular}

L.S.D (0.05) is 19.8 .

Very little quantity of $\mathrm{N}$ was accumulated in seeds of untreated plants (Table 4). Compared to canola received no $\mathrm{N}$ fertilizer, plants supplied with $90 \mathrm{~kg} \mathrm{~N}^{-1} \mathrm{fed}^{-1}$ produced seeds with $40.8 \%$ more N. On the other hand, ca. $23.1 \%$ more $\mathrm{N}$ was scored in seeds of 20 ton fed $^{-1} \mathrm{FYM}$ - amended plants in comparison with unamended ones. The impact of diazotroph formulation on seed $\mathrm{N}$ yield was less pronounced, where the highest increase of $15.9 \%$ was attributed to rhizobactren. Other inocula resulted in $1.9-12.3 \%$ increases in seed $\mathrm{N}$ content.

An average increase of $13 \%$ in seed oil content was recorded due to incorporation into soil of 20 ton FYM fed ${ }^{-1}$ (Table 5). Higher increases (up to $17 \%)$ were attributed to diazotroph inoculation particularly the rhizobactren formulation.

The promoting influence of mineral $\mathrm{N}$ fertilization on canola seed yield exceeded that due to either diazotroph or FYM treatment. The $90 \mathrm{~kg} \mathrm{~N}$ received plants contained ca. $26 \%$ more oil compared to those left without $\mathrm{N}$. 
J. Agric. Sci. Mansoura Univ., 34 (6), June, 2009

3

5899 
Table (4): Seed nitrogen content $\left(\mathrm{mg} \mathrm{plant}^{-1}\right)$ of canola due to diazotroph inoculation in presence of organic and mineral fertilization in clay soil.

\begin{tabular}{|c|c|c|c|c|c|c|}
\hline \multirow{2}{*}{$\begin{array}{l}\text { Mineral N } \\
\left(\text { kg fed }^{-1}\right)\end{array}$} & \multicolumn{6}{|c|}{ Biofertilizer formulations } \\
\hline & None & Biogen & Cerialen & Microbe & Nitroben & Rhizobactren \\
\hline & \multicolumn{6}{|c|}{ FYM $\left(0\right.$ ton fed $\left.^{-1}\right)$} \\
\hline 0 & 36.0 & 39.1 & $36 . \overline{0}$ & 43.2 & 47.5 & 48.0 \\
\hline 30 & 46.0 & 50.4 & 50.4 & 48.3 & 55.0 & 55.2 \\
\hline 60 & 57.5 & 55.2 & 55.2 & 50.6 & 57.6 & 65.0 \\
\hline \multirow[t]{2}{*}{90} & 62.3 & 57.5 & 59.3 & 60.0 & 60.0 & 60.0 \\
\hline & \multicolumn{6}{|c|}{ FYM (10 ton fed $\left.^{-1}\right)$} \\
\hline 0 & 40.8 & 43.2 & $4 \overline{5.8}$ & 43.7 & 48.0 & 50.6 \\
\hline 30 & 50.6 & 52.8 & 52.9 & 52.9 & 57.6 & 60.6 \\
\hline 60 & 60.0 & 68.4 & 67.6 & 65.8 & 72.9 & 70.0 \\
\hline \multirow[t]{2}{*}{90} & 61.2 & 56.1 & 64.4 & 61.2 & 61.2 & 67.4 \\
\hline & \multicolumn{6}{|c|}{ FYM (20 ton fed $\left.{ }^{-1}\right)$} \\
\hline 0 & 43.7 & 55.0 & 55.2 & 52.9 & 57.6 & 57.5 \\
\hline 30 & 60.1 & 53.8 & 60.0 & 59.8 & 63.1 & 64.4 \\
\hline 60 & 62.5 & 64.8 & 64.8 & 67.5 & 72.8 & 75.0 \\
\hline 90 & 72.5 & 69.6 & 69.6 & 78.2 & 81.3 & 84.5 \\
\hline
\end{tabular}

L.S.D. (0.05) is 17.1 .

Table. (5): Changes in seed oil content (g plant ${ }^{-1}$ ) of canola due to experimental treatments applied in clay soil.

\begin{tabular}{|c|c|c|c|c|c|c|}
\hline \multirow{2}{*}{$\begin{array}{l}\begin{array}{l}\text { Mineral N } \\
\left(\mathrm{kg} \mathrm{fed}^{-1}\right)\end{array} \\
\end{array}$} & \multicolumn{6}{|c|}{ Biofertilizer formulations } \\
\hline & None & Biogen & Cerialen & Microber & Nitroben & Rhizobactren \\
\hline & \multicolumn{6}{|c|}{ FYM (0 ton fed f $\left.^{-1}\right)$} \\
\hline 0 & 0.72 & 0.80 & $0.8 \overline{2}$ & 0.87 & 0.89 & 0.96 \\
\hline 30 & 0.94 & 0.97 & 1.02 & 0.98 & 1.01 & 1.08 \\
\hline 60 & 1.03 & 1.04 & 1.06 & 1.12 & 1.10 & 1.14 \\
\hline \multirow[t]{2}{*}{90} & 1.07 & 1.07 & 1.09 & 1.08 & 1.08 & 1.11 \\
\hline & \multicolumn{6}{|c|}{ FYM (10 ton fed $\left.{ }^{-1}\right)$} \\
\hline 0 & 0.81 & 0.89 & $1.0 \overline{1}$ & 0.88 & 0.94 & 1.01 \\
\hline 30 & 0.97 & 1.02 & 1.02 & 1.04 & 1.10 & 1.12 \\
\hline 60 & 1.11 & 1.27 & 1.18 & 1.39 & 1.21 & 1.48 \\
\hline \multirow[t]{2}{*}{90} & 1.18 & 1.21 & 1.18 & 1.19 & 1.09 & 1.21 \\
\hline & \multicolumn{6}{|c|}{ FYM $\left(20\right.$ ton fed $\left.^{-1}\right)$} \\
\hline 0 & 0.87 & 0.97 & 1.06 & 1.05 & 1.10 & 1.11 \\
\hline 30 & 1.01 & 1.18 & 1.10 & 1.02 & 1.13 & 1.12 \\
\hline 60 & 1.04 & 1.08 & 1.13 & 1.13 & 1.15 & 1.23 \\
\hline 90 & 1.15 & 1.18 & 1.29 & 1.39 & 1.31 & 1.28 \\
\hline
\end{tabular}

L.S.D. $(0.05)$ is 0.33 .

All the treatments applied in sand soil obviously promoted biomass production (Table 6). Irrespective of FYM level or microbial formula, the 90 $\mathrm{kg} \mathrm{N}$-fertilized plants were $30.9 \%$ heavier than the correspondings kept $\mathrm{N}$ free. On the other hand, very low increase percentage (11.8) was attributed to incorporation into soil of 20 ton $\mathrm{FYM} \mathrm{fed}^{-1}$. Again, rhizobactren kept its 
superiority among the diazotroph products resulting in the highest canola dry matter yield of $3.59 \mathrm{~g} \mathrm{pot}^{-1}$.

Table (6): Biomass yield $\left(\mathrm{g} \mathrm{pot}^{-1}\right)$ of canola grown in sand soil and treated with diazotrophs and fertilizers.

\begin{tabular}{|c|c|c|c|c|c|c|}
\hline \multirow{2}{*}{$\begin{array}{l}\text { Mineral N } \\
\left(\mathrm{kg} \mathrm{fed}^{-1}\right)\end{array}$} & \multicolumn{6}{|c|}{$\begin{array}{c}\text { Biofertilizer formulations } \\
\end{array}$} \\
\hline & None & Biogen & Cerialen & Microben & Nitroben & Rhizobactren \\
\hline & \multicolumn{6}{|c|}{ FYM $\left(0\right.$ ton fed $\left.^{-1}\right)$} \\
\hline 0 & 1.7 & 1.8 & 2.2 & 2.2 & 2.5 & 3.1 \\
\hline 30 & 2.0 & 2.6 & 2.6 & 2.6 & 2.9 & 3.0 \\
\hline 60 & 2.0 & 2.6 & 2.9 & 3.2 & 3.3 & 3.7 \\
\hline \multirow[t]{2}{*}{90} & 2.5 & 2.7 & 2.9 & 3.2 & 3.4 & 3.7 \\
\hline & \multicolumn{6}{|c|}{ FYM (10 ton fed f $\left.^{-1}\right)$} \\
\hline 0 & 2.0 & 1.9 & $2 . \overline{1}$ & 3.9 & 2.7 & 3.2 \\
\hline 30 & 2.1 & 2.6 & 2.8 & 2.8 & 3.2 & 3.8 \\
\hline 60 & 2.3 & 2.8 & 3.2 & 3.1 & 3.5 & 3.9 \\
\hline \multirow[t]{2}{*}{90} & 2.5 & 2.7 & 3.3 & 3.0 & 3.6 & 4.0 \\
\hline & \multicolumn{6}{|c|}{ FYM $\left(20\right.$ ton fed $\left.{ }^{-1}\right)$} \\
\hline 0 & 2.2 & 2.3 & 2.6 & 2.8 & 2.9 & 3.2 \\
\hline 30 & 2.4 & 2.7 & 2.8 & 3.1 & 3.2 & 3.7 \\
\hline 60 & 2.6 & 2.9 & 3.1 & 3.2 & 3.7 & 3.7 \\
\hline 90 & 2.9 & 3.0 & 3.1 & 3.1 & 3.6 & 4.1 \\
\hline
\end{tabular}

L.S.D. (0.05) is 3.1 .

More than $62 \%$ nitrogen was accumulated in seeds of canola supplied with $90 \mathrm{Kg} \mathrm{N}^{-1} \mathrm{fed}^{-1}$ (Table 7). Raising FYM from 0 to 10 ton fed ${ }^{-1}$, resulted in slight influence with increase of $13.7 \%$. Biofertilization occupied a medium rank among other treatments where increases in canola seed nitrogen ranged from 7.9 to $33.5 \%$.

As low as $0.71 \mathrm{~g} \mathrm{plant}^{-1}$ of oil was estimated for untreatment canola. Mineral $\mathrm{N}$ addition overcame the effect of either organic- or bio-fertilization (Table 8). Increase of $11.2 \%$ in canola seed yield was recorded for 20 ton FYM fed ${ }^{-1}$ - amended plants. Irrespective of organic- or inorganic fertilizers, up to $34 \%$ increase in seed oil yield was recorded for diazotroph inoculated plants.

The comparative response of canola to the various amendments in both clay and sand soils seems unavoidable. Table (9) shows that introduction of diazotroph inocula was more supportive to canola grown in sand soil than those cultivated in clay. Among the microbial inocula, rhizobactren acted more efficiently in comparison to other formulations.

Comparative variations in chemical characteristics of both soils due to diazotroph inoculation were very contradicting. Some inocula were more successful in improving sand properties, while others showed more pronounced modifying influence in the heavy textured clay soil (Table 10). All the introduced inocula had no appearant influence on organic matter content and EC measurements of both soils.

In the majority of cases, response of canola to mineral nitrogen application was more obvious in sand than clay soil. 
Ali, Shaimaa F. et al.

On the contrary to the effect of mineral and biofertilizers, canola grown in clay soil responded, to higher extent, to FYM compared to the sand soilcultivated correspondings (data not shown).

Table. (7): Seed nitrogen level $\left(\mathrm{mg} \mathrm{plant}^{-1}\right.$ ) of canola plants of the different experimental treatments applied in sand soil.

\begin{tabular}{|c|c|c|c|c|c|c|}
\hline \multirow{2}{*}{\begin{tabular}{|l|}
$\begin{array}{l}\text { Mineral N } \\
\left(\mathrm{kg} \mathrm{fed}^{-1}\right)\end{array}$ \\
\end{tabular}} & \multicolumn{6}{|c|}{ Biofertilizer formulations } \\
\hline & None & Biogen & Cerialen & Microben & Nitroben & Rhizobactren \\
\hline & \multicolumn{6}{|c|}{ FYM $\left(0\right.$ ton fed $\left.^{-1}\right)$} \\
\hline 0 & 20.8 & 25.2 & 28.2 & 33.0 & 34.2 & 38.0 \\
\hline 30 & 31.5 & 34.0 & 43.3 & 44.0 & 46.2 & 48.0 \\
\hline 60 & 38.0 & 44.1 & 48.5 & 52.3 & 56.7 & 57.2 \\
\hline \multirow[t]{2}{*}{90} & 60.9 & 64.0 & 63.4 & 60.2 & 62.0 & 58.9 \\
\hline & \multicolumn{6}{|c|}{ FYM $\left(10\right.$ ton fed $\left.^{-1}\right)$} \\
\hline 0 & 27.4 & 30.4 & 34.0 & 36.0 & 40.2 & 48.3 \\
\hline 30 & 37.4 & 43.1 & 40.2 & 46.2 & 52.5 & 55.8 \\
\hline 60 & 46.2 & 49.4 & 47.7 & 50.2 & 53.0 & 65.8 \\
\hline \multirow[t]{2}{*}{90} & 60.2 & 60.0 & 62.1 & 60.0 & 58.7 & 67.6 \\
\hline & \multicolumn{6}{|c|}{ FYM (20 ton fed f $\left.^{-1}\right)$} \\
\hline 0 & 31.7 & 36.3 & $38 . \overline{0}$ & 42.2 & 46.0 & 59.4 \\
\hline 30 & 39.6 & 42.0 & 43.9 & 52.0 & 49.4 & 58.0 \\
\hline 60 & 55.9 & 55.0 & 51.3 & 59.8 & 64.5 & 58.1 \\
\hline 90 & 59.2 & 66.0 & 67.2 & 47.0 & 72.4 & 64.6 \\
\hline
\end{tabular}

Table. (8): Effect of inoculation and fertilization treatments on seed oil yield $\left(\mathrm{g} \mathrm{plant}^{-1}\right)$ of canola grown in sand soil.

\begin{tabular}{|c|c|c|c|c|c|c|}
\hline \multirow{2}{*}{\begin{tabular}{|l|} 
Mineral N \\
$\left(\mathrm{kg} \mathrm{fed}^{-1}\right)$
\end{tabular}} & \multicolumn{6}{|c|}{ Biofertilizer formulations } \\
\hline & None & Biogen & Cerialen & Microbe & Nitroben & Rhizobactren \\
\hline & \multicolumn{6}{|c|}{ FYM (0 ton fed f $\left.^{-1}\right)$} \\
\hline 0 & 0.71 & 0.71 & 0.83 & 0.82 & 0.79 & 0.72 \\
\hline 30 & 0.72 & 0.86 & 0.99 & 1.05 & 1.02 & 1.16 \\
\hline 60 & 1.02 & 0.99 & 1.09 & 1.17 & 1.27 & 1.41 \\
\hline \multirow[t]{2}{*}{90} & 1.33 & 1.45 & 1.33 & 1.41 & 1.41 & 1.41 \\
\hline & \multicolumn{6}{|c|}{ FYM (10 ton fed-1) } \\
\hline 0 & 0.64 & 0.75 & $0.8 \overline{3}$ & 0.86 & 0.98 & 1.14 \\
\hline 30 & 0.80 & 0.97 & 0.95 & 1.03 & 1.18 & 1.31 \\
\hline 60 & 1.01 & 1.13 & 1.16 & 1.36 & 1.28 & 1.51 \\
\hline \multirow[t]{2}{*}{90} & 1.34 & 1.34 & 1.35 & 1.23 & 1.38 & 1.43 \\
\hline & \multicolumn{6}{|c|}{ FYM (20 ton fed $\left.{ }^{-1}\right)$} \\
\hline 0 & 0.72 & 0.82 & 0.91 & 1.00 & 1.10 & 1.30 \\
\hline 30 & 0.83 & 0.92 & 1.05 & 1.19 & 1.20 & 1.35 \\
\hline 60 & 1.09 & 1.17 & 1.24 & 1.23 & 1.39 & 1.40 \\
\hline 90 & 1.43 & 1.47 & 1.42 & 1.36 & 1.47 & 1.51 \\
\hline
\end{tabular}


Table. (9): Change percentages in growth parameters of canola grown in clay and sand soils due to inoculation with diazotroph preparations (related to unioculated plants).

\begin{tabular}{|c|c|c|c|c|c|}
\hline & Biogen & Cerialen & Microben & Nitroben & Rhizobactern \\
\hline & \multicolumn{5}{|c|}{ Biomass yield $\left(\mathrm{g} \mathrm{pot}^{-1}\right)$} \\
\hline \multirow{3}{*}{$\begin{array}{l}\text { Clay } \\
\text { Sand }\end{array}$} & 10.3 & 16.7 & 24.3 & 32.8 & 44.7 \\
\hline & 11.9 & 23.5 & 27.9 & 41.6 & 58.4 \\
\hline & \multicolumn{5}{|c|}{ Nitrogen yield $\left(\mathrm{mg} \mathrm{pot}^{-1}\right)$} \\
\hline Clay & 14.1 & 18.3 & 24.4 & 30.9 & 46.8 \\
\hline \multirow[t]{2}{*}{ Sand } & \multirow{2}{*}{\multicolumn{5}{|c|}{ Plant phosphorus uptake (mg pot $\left.{ }^{-1}\right)$}} \\
\hline & & & & & \\
\hline Clay & 17.0 & $22 . \overline{4}$ & 28.8 & 34.6 & 49.0 \\
\hline \multirow[t]{2}{*}{ Sand } & \multirow{2}{*}{\multicolumn{5}{|c|}{ Plant potassium uptake $\left(\mathrm{mg} \mathrm{pot}^{-1}\right)$}} \\
\hline & & & & & \\
\hline Clay & 8.4 & 14.9 & 21.1 & 33.1 & 45.0 \\
\hline Sand & \multicolumn{5}{|c|}{ Oil yield $\left(\mathrm{g} \mathrm{plant}^{-1}\right)$} \\
\hline Clay & 6.1 & 9.1 & 10.1 & 10.1 & 17.2 \\
\hline Sand & 8.2 & 13.4 & 17.5 & 23.7 & 34.0 \\
\hline
\end{tabular}

Table (10). Change percentages in soil chemical properties of clay and sand soils as affected by diazotroph inocula (related to controls).

\begin{tabular}{|c|c|c|c|c|c|}
\hline & Biogen & Cerialen & Microben & Nitroben & Rhizobactern \\
\hline \multirow{3}{*}{$\begin{array}{l}\text { Clay } \\
\text { Sand }\end{array}$} & \multicolumn{5}{|c|}{ Organic matter(\%) } \\
\hline & 0 & 0 & 0 & 0 & 0 \\
\hline & 0 & 0 & ${ }^{0} \mathrm{pH}$ & -3.1 & 0 \\
\hline Clay & -0.1 & 0 & -0.13 & 0 & -0.1 \\
\hline Sand & 2.6 & \multicolumn{4}{|c|}{$E C\left(d_{S m}^{-1}\right)$} \\
\hline Clay & 0 & 0 & 0 & 0 & 0 \\
\hline Sand & 0 & 0 & \multicolumn{2}{|c|}{ Available N (ppm) } & 0 \\
\hline Clay & 0.7 & -0.03 & 0 & 0 & 0.03 \\
\hline Sand & 0.6 & -0.6 & $\begin{array}{c}0.2 \\
\text { Available } \mathrm{P}\end{array}$ & om) & 0.3 \\
\hline Clay & 0 & -0.1 & 0.1 & -0.3 & 0.1 \\
\hline Sand & -0.09 & -0.09 & $\begin{array}{c}0.3 \\
\text { Available K }\end{array}$ & om) & 0 \\
\hline $\begin{array}{l}\text { Clay } \\
\text { Sand }\end{array}$ & $\begin{array}{l}-0.08 \\
0.5\end{array}$ & $\begin{array}{l}-0.15 \\
0.2\end{array}$ & $\begin{array}{c}0 \\
0.7 \\
\text { Available wat }\end{array}$ & $\begin{array}{r}0.02 \\
-0.02\end{array}$ & $\begin{array}{l}-0.4 \\
0.8\end{array}$ \\
\hline Clay & .8 & 8.1 & 7.9 & 7.5 & 8.8 \\
\hline Sand & 2.1 & 1.8 & 1.7 & 1.7 & 1.7 \\
\hline
\end{tabular}

No significant differences in bulk density of either soil type were attributed to biofertilizer nature, where the estimates varied between 1.2 and $1.3 \mathrm{Mg} \mathrm{m}^{-3}$ (Table 11). Inoculum quantity exhibited no effect as well. Bulk density of sand soil was higher than that of clay soil; ranges were $1.5-1.6 \mathrm{Mg}$ $\mathrm{m}^{-3}$ for the former and $1.2-1.3 \mathrm{Mg} \mathrm{m}^{-3}$ for the latter. 
Ali, Shaimaa F. et al.

Table. (11): Variations in bulk density $\left(\mathrm{Mg} \mathrm{m}^{-3}\right)$ of soils among the different bacterial inocula.

\begin{tabular}{|c|c|c|c|c|c|c|}
\hline \multirow{3}{*}{ Product } & \multicolumn{6}{|c|}{ Inocula quantity $\left(\mathrm{g} \mathrm{fed}^{-1}\right)$} \\
\hline & \multicolumn{3}{|c|}{ Clay soil } & \multicolumn{3}{|c|}{ Sand soil } \\
\hline & 200 & 400 & 600 & 200 & 400 & 600 \\
\hline None & 1.30 & 1.30 & 1.30 & 1.58 & 1.58 & 1.58 \\
\hline Biogen & 1.26 & 1.25 & 1.23 & 1.52 & 1.51 & 1.50 \\
\hline Cerialen & 1.26 & 1.23 & 1.23 & 1.50 & 1.48 & 1.45 \\
\hline Microben & 1.30 & 1.28 & 1.27 & 1.56 & 1.54 & 1.52 \\
\hline Nitroben & 1.30 & 1.29 & 1.28 & 1.55 & 1.55 & 1.53 \\
\hline Rhizobactren & 1.26 & 1.23 & 1.22 & 1.50 & 1.48 & 1.47 \\
\hline L.S.D.(0.05) & \multicolumn{3}{|c|}{0.03} & \multicolumn{3}{|c|}{0.02} \\
\hline
\end{tabular}

Slight increases in total porosity percentages were obtained for inoculated soils (Table 12). Raising the inoculum level from $200 \mathrm{~g}$ to $600 \mathrm{~g}$ fed $^{-1}$ scored ca. $2 \%$ increase in total porosity of clay soil.

The influence of biofertilization on total porosity was more obvious in sand soil. Increases of 2.2-11.8\% were recorded due to soil inoculation. As the inoculum amount increased from $200 \mathrm{~g}$ to $600 \mathrm{~g} \mathrm{fed}^{-1}$, total porosity increased by ca. $8 \%$. Compared to others, cerialen particularly at the highest rate of application was the most supportive to improve sand soil total porosity.

Table. (12): Total porosity percentages of clay and sand inoculated with microbial preparations.

\begin{tabular}{|l|llc|crr|}
\hline \multirow{2}{*}{ Broduct } & \multicolumn{5}{c|}{ Inocula quantity (g fed $\mathbf{~}^{-1}$ ) } \\
\cline { 2 - 7 } & \multicolumn{5}{c|}{ Clay soil } & \multicolumn{3}{c|}{ Sand soil } \\
\cline { 2 - 7 } & $\mathbf{2 0 0}$ & $\mathbf{4 0 0}$ & $\mathbf{6 0 0}$ & $\mathbf{2 0 0}$ & $\mathbf{4 0 0}$ & $\mathbf{6 0 0}$ \\
\hline None & 51.0 & 51.0 & 51.0 & 40.8 & 40.8 & 40.8 \\
Biogen & 52.2 & 52.8 & 53.3 & 43.0 & 42.1 & 44.0 \\
Cerialen & 52.8 & 52.7 & 53.2 & 43.9 & 44.7 & 45.6 \\
Microben & 50.9 & 51.4 & 52.3 & 41.7 & 42.2 & 43.1 \\
Nitroben & 50.9 & 51.0 & 51.5 & 42.1 & 42.2 & 42.9 \\
Rhizobactren & 52.3 & 53.2 & 53.7 & 43.9 & 44.6 & 44.9 \\
\hline L.S.D.(0.05) & 0.9 \\
\hline
\end{tabular}

\section{DISCUSSION}

Increased attention is now being paid to develop an Integrated Plant Nutrition System (IPNS) that maintains or enhance soil productivity through balanced use of all sources of nutrients; including chemical-, organic- and bio- fertilizers. The basic concept underlying the IPNS is the adjustment of soil fertility and plant nutrient supply to an optimum level for sustaining the appropriate crop productivity through optimization of the benefits from all possible sources of plant nutrients in an integrated manner. The present work introduces some information on the applicability of the IPNS concept to ameliorate canola seed and oil yields, a necessity for rationalization of agrochemical inputs in agriculture.

The organic fertilizer used in the present study was the farm yard manure (FYM) which is a traditional organic fertilizer readily available to 
farmers. Result showed an increase of $4 \%$ in biomass yield of canola attributed to incorporation into clay soil of 10 ton $\mathrm{FYM} \mathrm{fed}^{-1}$. Raising the organic fertilizer level to 10 ton fed $^{-1}$ resulted in $10.5 \%$ more biomass production. Moreover, the application of FYM enhanced $\mathrm{N}$ assimilation by plants. An average percentage increase of 14.9 was obtained due to addition of 10 ton fed $\mathrm{d}^{-1}$, while 20 ton fed $\mathrm{d}^{-1}$ - amended canola recoded an extra increase of $36.4 \%$. Similarly, plants cultivated in sand soil positively responded to FYM application.

No much work has been done in respect to the effect of FYM in combination with inorganic $\mathrm{N}$ fertilizer on canola seed oil yield. In spite of having relatively high levels of nutrients, the FYM have somewhat low nitrogen content. This was the major reason for combining the FYM application with mineral nitrogen fertilizer. For canola grown in clay soil received 10 ton $\mathrm{FYM} \mathrm{fed}^{-1}$, raising the mineral $\mathrm{N}$ level from 60 to $90 \mathrm{~kg} \mathrm{fed}^{-1}$ resulted in $23 \%$ increase in plant $\mathrm{N}$ content. Lower increase $(16.3 \%)$ was scored for 20 ton fed $^{-1}$ treated plants. Respective increases of 8.2 and 10.2 $\%$ were obtained for the correspondings cultivated in sand soil.

As mentioned by Hocking et al. (2003), economic yields of canola can not be obtained without adequate fertilization if the crop is grown in soils deficient in essential elements.

Compared to most other grain crops in Egypt, canola has a greater requirement for nutrient inputs to secure high yield. Therefore, the experimental design of the present work included the application of as high as $90 \mathrm{~kg} \mathrm{~N} \mathrm{fed}^{-1}$. As reported by Hocking et al. (1997), canola needs ca. 25 $\%$ more $\mathrm{N}, \mathrm{P}$ and $\mathrm{K}$ and up to 5 times more $\mathrm{S}$ than wheat to balance fertilizer inputs with nutrient removal in grains. In Egypt, the crop is traditionally grown after a legume as break crop for wheat and because of the high mineral $\mathrm{N}$ status of the soil. However, there is an increasing trend to cultivate canola more frequently in longer cropping sequences when soil mineral is low, so that large applications of $\mathrm{N}$ fertilizer are required for high yields.

Interestingly, the effect of organic manure in increasing soil available $\mathrm{N}$ levels overcame that of urea. For instance, incorporation into soil of FYM @ the rate of 20 ton $\mathrm{fed}^{-1}$ increased available $\mathrm{N}$ content of clay soil by $81.7 \%$ while only $11.3 \%$ increase was attributed to $90 \mathrm{~kg} \mathrm{~N}^{-1}$ dressing. An explanation for such difference is that FYM is considered as a slow release $\mathrm{N}$ fertilizer which supplies soil with $\mathrm{N}$ in successive doses. In contrast, urea-N is known to be lost via ammonia volatilization particularly in alkaline soils and under high temperature prevailing in Egyptian environments.

The lack of a clear agronomic and economic rationale for variable fertilization rates remains a formidable barrier to deal with this approach. In their discussion on seeding rates in corn, Bullock et al. (1998) stated that the major limitation to adopt variable rate technology is the lack of knowledge about the effects of site characteristics, i.e. soil texture and organic matter content on yield response. Without this knowledge, the technology on its own is of no economic benefit to farmers. One of the major objectives of this study was to assess the response of canola growth and seed yield to organic and inorganic fertilization in two soils of different textural classes with variable organic matter levels based on 180 day pot experiment. Here, response of 


\section{Ali, Shaimaa F. et al.}

plants to $\mathrm{N}$ addition was more obvious in sand than clay soil, an observation was more clear with seed oil yield. On the contrary to the effect of mineraland bio-fertilizers, canola grown in clay soil responded better to FYM application.

Response of canola to bacterial inoculation was better in sand soil compared to that reported in the clay one. The compact soil structure may have inhibited easy penetration and proliferation of growing roots particularly during early periods. Rubatzky et al. (1999) reported that clay soils are usually less adapted to intensive vegetable production because of possible aeration and drainage limitations that may restrict nutrient acquisition and root development. Formation of crust due to poor infiltration capacity of the soil during irrigation could also contribute towards low root yields.

The experimental design of the present work included the introduction of five diazotroph formulations into the organic- and inorganic-fertilization schedule. Besides the ability of diazotrophs to fix $\mathrm{N}_{2}$, they are known to produce a number of plant hormones that support root development. A comparison among such preparation is a necessity for better selection.

Irrespective of chemical or organic fertilization, the root: shoot ratios foe canola dry matter yields increased due to all the products applied in sand soil particularly microben $(20 \%)$. Lower increase of $<6 \%$ was scored for biogen inoculated plants grown in clay soil. As to that yields, cerialen was the only preparation that supported canola root growth in clay soil with $>14 \%$ increase in root: shoot ratio, otherness, no effect was noticed with plants cultivated in sand where ratios kept constant among all the applied inocula.

Organic and/or inorganic fertilizers not only serve to maintain or improve crop yields, but they directly or indirectly change the physical, chemical and biological properties of soil. These changes, in the long-term, are believed to have significant influences on the quality and productive capacity of soil (Acton and Gregorich, 1995). However, available information is conflicting and uncertainties still remain about the short-term effects. Few attempts have been made on soil quality changes that have occurred in response to short-term management practices imposed.

Soil $\mathrm{pH}$, in general, ranged from 7.9 to 8.11 . Treatments received either mineral $\mathrm{N}$ fertilizer or diazotroph inoculants showed no significant differences on $\mathrm{pH}$. In contrast, FYM induced $\mathrm{pH}$ decreases of 0.42 and 0.40 $\mathrm{pH}$ units in clay and sand soils respectively. This confirms the findings of Aref and wander (1998) who observed lowering of soil pH due to fertilizer application. The $\mathrm{N}$-containing fertilizers, unless specially treated, tend to acidify soil. This is mainly due to the fact that most fertilizers supply $\mathrm{NH}_{4}{ }^{+}$or result in its production via ammonification. Upon oxidation, $\mathrm{NH}_{4}{ }^{+}$can release $\mathrm{H}^{+}$ions which are potential source of soil acidity (Magdoff et al., 1997). It has to be realized that the experiment of the present study is a short-term which substantially differ from long-term ones. Belay et al. (2002) mentioned that long-term fertilizer applications, especially of $\mathrm{N}$, had acidifying effects resulting in low-pH soils.

Although extensive laboratory studies have been carried out on the effect of organic materials on soil physical characteristics (Barzegar et al., 1997; Ferrini et al., 2005), none did validate the results on the influence of 
biofertilizers. The present study introduces original information on the quantitative impact of the five bacterial formulations, at three rates on some physical properties of clay and sand soils. Measured bulk density values ranged from 1.2 to 1.3 and 1.5 to $1.6 \mathrm{Mg} \mathrm{m}^{-1}$ for respective soils, with no significant differences due to bacterial treatment. The failure of biofertilizers to modify soil bulk density might be attributed to the short experimentation period, since Eghball (2002) emphasizes on the long- term experiments of at least 3 years for positive modification of soil bulk density. In such case, as soil water content increases from air-dry, water films provie lubrication between soil particles, allowing the particles to slip and from a closer packing (increased density) when a load is applied. As water is added to soil, the amount of water occupying soil pore space increases, and the pore spaces occupied by water are unable to receive soil particles during load application. The lubrication and pore-filling influences of water are present at all levels of water content. Lubrication, however, is of greater importance when the soil is relatively dry while pore-filling is of special concern when soil is relatively wet. When the "lubrication effect" increases more rapidly than the "pore-filling effect", there is an increase in bulk density with increased water content. When the "lubrication effect" increases slower than the "pore-filling effect", there is a decrease in dry bulk density with increased water content.

Biofertilizer formulations used in the present study did slightly increase total porosity of soils. This particular physical property hardly fluctuated among the applied inocula. Raising the inoculum level from $200 \mathrm{~g}$ to $600 \mathrm{~g}$ fed $^{-1}$ scored ca. $2 \%$ increase in total porosity of clay soil, increases were 2.2 $-11.8 \%$ in sand soil. High soil porosity results in greater root distribution and perpetration and hence better water and nutrient uptake.

Seed oil is the most important component of canola, therefore it was evaluated at harvest in response to the experimental amendments. The oil yield varied from one treatment to another but generally increased due to addition of either fertilizer or all in combination. The estimated levels of seed oil were falling in the rage 41.6 - $50 \%$ depending upon treatment. Such estimates are almost similar to those found by Yan (1990) who found $40-44$ $\%$ oil in canola well - developed seeds. The author mentioned that the fatty acid composition of canola seed oil is genetically more variable than probably the composition of any other major vegetable oil. Canola oil contains traces of eruric acid, 5 - $8 \%$ saturated fats, $60-65 \%$ nonsaturated fats and $30-$ $35 \%$ of polysaturated fats. Mutants with significant elevated nonsaturated levels exist.

Among the advantages of canola cultivation, particularly in marginal soils, is soil furnishing with adequate supply of nitrogen and other necessary nutrients for the next crop. Past research in Georgia (Hocking, 2003) indicated that although canola takes up more than $180 \mathrm{lb} \mathrm{acre}^{-1}$ of nitrogen and potassium besides significant amounts of phosphorus, calcium, magnesium and sulfur, the plant can leave fairly high quantities of nitrogen to be available for the summer crop following it.

Finally, much work is needed on different fertilization schemes in connection with various canola varieties to gain a better understanding in terms of their interaction effects on the parameters discussed here and to 


\section{Ali, Shaimaa F. et al.}

develop effective methods for regularly testing the product quality. The prospective ultimate goal is to tailor the fertilizing regime to the soil, climate and crop in a way that offers both a good yield of a healthy product with high nutrient value.

\section{REFERENCES}

Acton, D. F. and Gregorich, L. J. (1995) The heath of our soils: toward sustainable agriculture in Canada. Agriculture Agri-food Canada, CDR Unit, Ottawa.

A.O.A.C. (1985). Association of Official Agricultural Chemists. Official Methods of Analysis. A.O.A.C. 14 ${ }^{\text {th }}$ Washingtion D.C.,U.S.A.

Aref, S. and Wander, M. M. (1998). Long-term trends of corn yield and soil organic matter in different crop sequences and soil fertliy treatments on the Morrow Plots. Adv. Agro., 62:153-161.

Barzegar, A. R.; Nelson, P.N.; Oades, J. M. and Rengasamy, P. (1997). Organic matter, sodicity and clay type: Influence on aggregation. Soil Sci. Soc. Am. J., 61:1131-1137.

Belay, A.; Claassens, A. S. and Wehner, F. C. (2002). Effect of direct nitrogen and potassium and residual phosphorus fertilizers on soil chemical properties, microbial components and maize yield under long-term crop rotation. Biol. Fertil. Soils, 35:420-427.

Bullock, D. G.; Bullock, D.S.; Nafzibger, E.D.; Doerge, T. A.; Paskiewicz, S. R.; Carter, P. R. and Peterson, T. A. (1998).Does variable rate seeding of corn pay? Agron. J., 90:830-836.

Eghball, B. (2002). Soil properties as influenced by phosphorus- and nitrogen-based manure and compost applications. Agron. J., 94:12135.

Ferrini, F.; Giuntoli, A.; Nicese, F. P.; Pellegrini, S. and Vignozzi, N. (2005).Effect of fertilization and backfill amendments on soil characteristics, growth, and leaf gas exchange of English oak (Quercus robur I.). J. Arboriculture, 31(4):182-190.

Hocking, P. J.; Randall, P. J.; De Marko, D. and Bamforth, I. (1997). Assessment of the nitrogen status of field-grown canola (Brassica napus) by plant analysis. Aust. J. Exp.Agric. 337:83-92.

Hocking, P. J.; Mead, J. A.; Good, A. J. and Diffey, S. M. (2003). The response of canola (Brassica napus L.) to tillage and fertilizer placement in contrasting environments in southern New South Wales. Aust. J. Exp. Agric., 43:1323-1333.

Kennedy, I. R. and Tchan, Y. T. (1992). Biological nitrogen fixation in non leguminous field crops: Recent advances. Plant Soil, 141:93-118.

Khalil, I. A. and Rehman, H. (1999). Qualitative genetic variation for oil content in several maize genotypes. Sarhad J. Agric., 15:59-62.

Klute, A. (1982). Methods of Analysis Part-1: Physical and Mineralogical Methods ( $\left.2^{\text {nd }} \mathrm{ed}\right)$. American Society of Agronomy, Madison, Wisconsim, U.S.A. 
Magdoff, F.; Lanyon, L. and Liebhardt, B. (1997) Nutrient cycling, transformations and flows: Implications for a more sustainable agriculture. Adv. Agro., 60:1-73.

Mytton, L. (1993). Nitrogen fixation. In Institute of Grassland and Environmental Research Rep. Inst. Grassland and Environ. Res., Aberystwyth, UK., pp: 46-50.

Page, A. L.; Miller, R. H. and Keeny, D. R. (1982). Methods of Soil Analysis Par-2: Chemical and Microbiological Properties. (2 ${ }^{\text {nd }}$ ed)- American Society of Agronomy Madisons, Wisconsim, U.S.A.

Rubatzky, V. E., Quiros, C. F. Simon, P. W. (1999). Carrots and related vegetable Umbeliferae, p 294.

Snedecor, G. W. and W. G. Cochran (1980). Statistical Methods, $7^{\text {th }}$ Edin lowa State Press, lowa, U.S.A.

Yan, Z. (1990). Overview of rapeseed production and research in China. Proc. Int. Canola Conf. Potash \& Phosphate Institute, Atlanta, P: 2935.

Yasari, E. and Patwardhan, A. M. (2007). Effect of Azotobacter and Azosprillium inoculants and chemical fertilizers on growth and productivity of canola (Bassica napus L.). Asian J. Plant Sci. 6(1):7782.

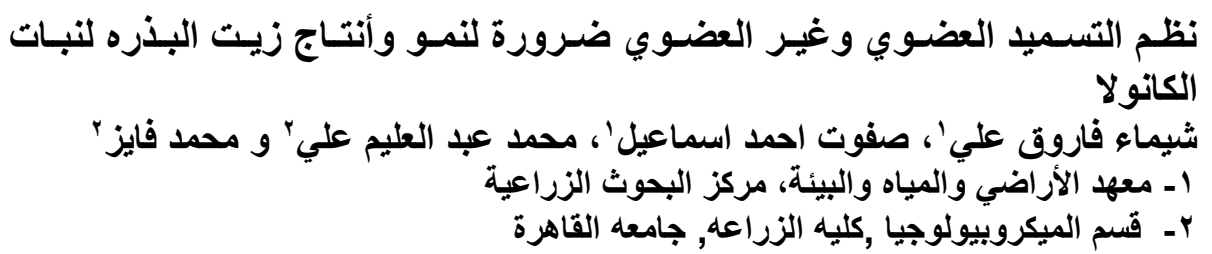

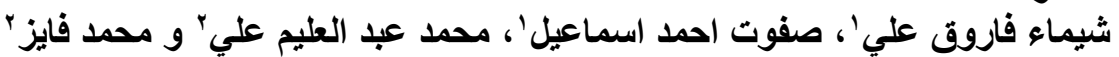

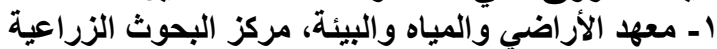

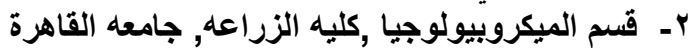

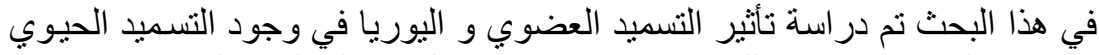

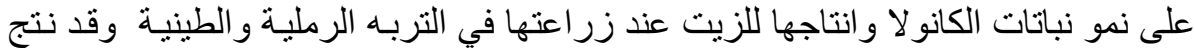

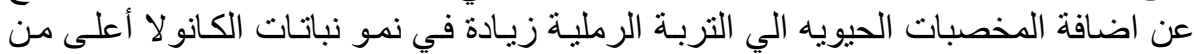

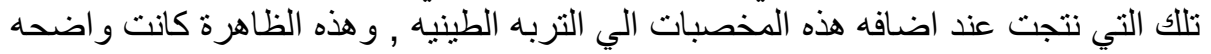

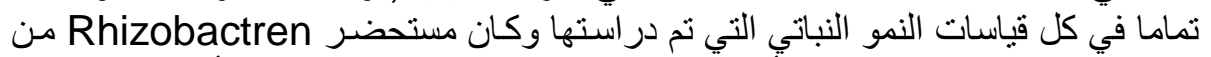

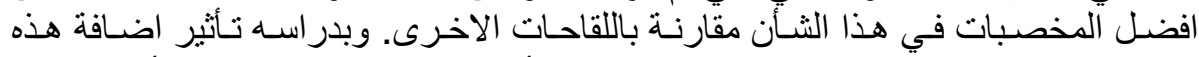

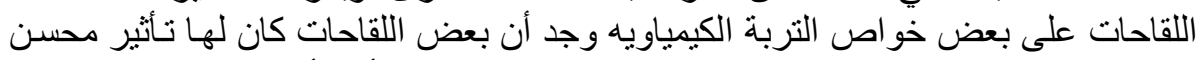

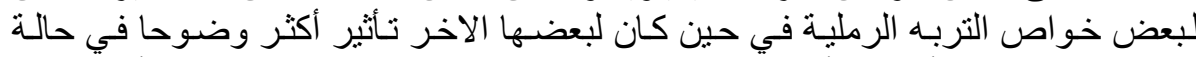

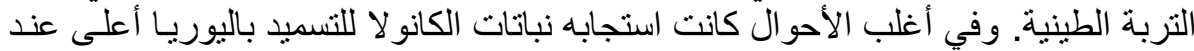

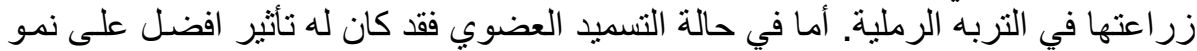

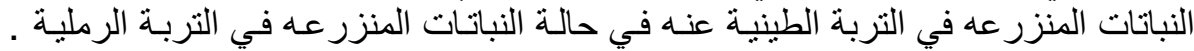

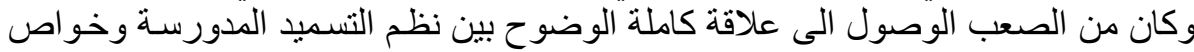
التربة الكيماويه خاصه مع قصر عمر التجربه. 
Table (3): Phosphorus and potassium uptake $\left(\mathrm{mg} \mathrm{pot}^{-1}\right)$ of canola grown in clay soil as affected by fertilization and inoculation treatments.

\begin{tabular}{|c|c|c|c|c|c|c|c|c|c|c|c|c|}
\hline \multirow{3}{*}{\begin{tabular}{|l}
$\begin{array}{l}\text { Mineral N (kg } \\
\left.\text { fed }^{-1}\right)\end{array}$ \\
\end{tabular}} & \multicolumn{6}{|c|}{ Phosphorus } & \multicolumn{6}{|c|}{ Potassium } \\
\hline & \multicolumn{2}{|c|}{ None Biogen } & \multicolumn{2}{|c|}{ Microben } & \multicolumn{2}{|c|}{ Nitroben Rhizobactren } & \multirow{2}{*}{$\begin{array}{l}\text { None Biogen } \\
\text { on fed } \text { fed }^{-1}\end{array}$} & \multirow{2}{*}{\multicolumn{2}{|c|}{ Cerialen }} & Microben & \multicolumn{2}{|c|}{ Nitroben Rhizobactren } \\
\hline & & & & & & FYM (C & & & & & & \\
\hline 0 & 24.0 & 29.4 & 30.5 & 39.4 & 37.7 & 46.6 & 45.5 & 48.5 & 50.3 & 58.9 & 62.2 & 81.2 \\
\hline 30 & 25.2 & 34.4 & 38.9 & 40.0 & 40.0 & 48.3 & 48.7 & 60.2 & 66.0 & 71.0 & 71.0 & 75.9 \\
\hline 60 & 30.6 & 40.0 & 42.1 & 45.4 & 48.3 & 52.2 & 61.8 & 60.5 & 71.9 & 67.5 & 79.8 & 78.8 \\
\hline \multirow[t]{2}{*}{90} & 34.2 & 41.6 & 42.1 & 44.3 & 46.9 & 51.0 & 74.0 & 63.4 & 69.4 & 68.3 & 80.4 & 90.5 \\
\hline & \multicolumn{12}{|c|}{ FYM $\left(10\right.$ ton fed $\left.{ }^{-1}\right)$} \\
\hline 0 & 31.9 & 34.4 & 34.4 & 39.9 & 40.0 & 46.8 & 61.7 & 68.7 & 67.1 & 74.1 & 86.5 & 93.3 \\
\hline 30 & 35.5 & 42.1 & 43.8 & 46.7 & 46.6 & 48.8 & 69.1 & 82.0 & 74.1 & 86.0 & 92.0 & 105.1 \\
\hline 60 & 39.8 & 45.6 & 49.1 & 46.6 & 50.0 & 58.5 & 72.5 & 81.0 & 89.1 & 90.4 & 99.3 & 111.4 \\
\hline \multirow[t]{2}{*}{90} & 39.9 & 46.8 & 46.6 & 46.6 & 47.5 & 54.0 & 74.7 & 83.7 & 92.1 & 85.5 & 102.6 & 105.9 \\
\hline & \multicolumn{12}{|c|}{ FYM (20 ton fed $\left.{ }^{-1}\right)$} \\
\hline & 37.4 & 43.6 & 51.1 & 55.2 & 56.8 & 58.1 & 68.2 & 81.0 & 79.1 & 97.5 & 103.4 & 111.6 \\
\hline 30 & 45.9 & 52.8 & 56.0 & 55.5 & 63.5 & 64.5 & 83.6 & 88.2 & 104.6 & 112.7 & 117.7 & 129.6 \\
\hline 60 & 51.5 & 55.5 & 58.1 & 59.3 & 64.7 & 71.3 & 100.0 & 104.4 & 109.3 & 114.3 & 118.6 & 134.1 \\
\hline 90 & 54.1 & 60.7 & 58.1 & 60.8 & 64.5 & 71.6 & 97.5 & 107.6 & 113.1 & 112.1 & 128.3 & 126.8 \\
\hline L.S.D. (0.05) & \multicolumn{6}{|c|}{5.2} & \multicolumn{6}{|c|}{16.5} \\
\hline
\end{tabular}

